\title{
PERLINDUNGAN HUKUM TERHADAP KORBAN TINDAK PIDANA KEKERASAN DALAM RUMAH TANGGA YANG MENGAKIBATKAN LUKA BERAT (STUDI PUTUSAN NOMOR: 992 K/PID.SUS/2017)
}

\section{LEGAL PROTECTION AGAINST VICTIMS OF CRIMINAL ACTS OF DOMESTIC VIOLENCE THAT CAUSE SERIOUS INJURY}

(STUDY DECISION NUMBER: 992 K/PID.SUS/2017)

\author{
Amsori, AA Rohmatulloh \\ Sekolah Tinggi Ilmu Hukum IBLAM \\ Kramat Raya No.25 Senen Jakarta Pusat \\ amsori.sh@gmail.com
}

$\begin{array}{ll}\text { Submission } & : \text { 17 Januari } 2022 \\ \text { Accepted } & : \text { 25 Januari } 2022 \\ \text { Publish } & : \text { 31 Januari } 2022\end{array}$

\begin{abstract}
This study aims to determine the legal protection for victims of domestic violence and to find out the judge's legal considerations in making decisions on cases of criminal acts of domestic violence that resulted in serious injuries in case Number: 992 K/Pid.sus/2017. The type of research in this thesis is Juridical Normative Law Research. Normative Legal Research is a legal research method that principally conducts research on legal rules in legislation, jurisprudence and doctrine which is carried out qualitatively. From the research conducted, the authors get the following results: First, that legal protection for victims of criminal acts of domestic violence is an effort to recover victims of domestic violence, which is an integral part of the legal process. In this case, it is a shared responsibility between the government and service providers, including medical, psychological, legal and safe house services. Second, that based on the author's analysis, the consideration of the Supreme Court Judge in case Number: 992 K/Pid.Sus/2017 contradicts the authority of the judex juris because he did not receive a cassation request from the Public Prosecutor who clearly questioned the application of the law in judex facti. So, the author should state that the Supreme Court Judge's Decision Number: 992 K/Pid.Sus/2017 does not contain a sense of justice and does not contain the principle of law enforcement.
\end{abstract}

Keywords: Crime, Domestic Violence, Serious Injury 


\begin{abstract}
Abstrak
Penelitian ini bertujuan untuk mengetahui perlindungan hukum terhadap korban kekerasan dalam rumah tangga dan untuk mengetahui pertimbangan hukum hakim dalam menjatuhkan putusan terhadap kasus tindak pidana kekerasan dalam rumah tangga yang mengakibatkan luka berat pada perkara Nomor: 992 K/Pid.sus/2017. Jenis Penelitian dalam Skripsi ini adalah Penelitian Hukum Normatif Yuridis. Penelitian Hukum Normatif adalah Metode penelitian Hukum yang ada prinsipnya dilakukan penelitian terhadap kaidah hukum dalam Perundang-undangan, Yurisprudensi dan Doktrin yang dilakukan secara kualitatif. Dari penelitian yang dilakukan, penulis mendapat hasil sebagai berikut: Pertama bahwa perlindungan hukum terhadap korban tindak pidana Kekerasan dalam Rumah tangga adalah upaya pemulihan korban KDRT menjadi salah satu hal yang tidak terpisahkan dari proses hukum. Dalam hal ini sudah menjadi tanggung jawab bersama antara pemerintah dan penyedia layanan baik layanan medis, psikologis, hukum dan rumah aman. Kedua bahwa berdasarkan analisis penulis pertimbangan Hakim Mahkamah Agung dalam perkara Nomor : 992 K/Pid.Sus/2017 bertentangan dengan kewenangan judex juris karena tidak menerima permohonan kasasi dari Penuntut Umum yang secara jelas mempermasalahkan penerapan hukum pada judex facti. Maka, penulis patut menyatakan bahwa Putusan Hakim Mahkamah Agung Nomor: 992 K/Pid.Sus/2017 tidak memuat rasa keadilan dan tidak memuat prinsip penegakan hukum.
\end{abstract}

\title{
Kata Kunci : Tindak Pidana, Kekerasan Dalam Rumah Tangga, Luka Berat
}

\section{A. Pendahuluan}

Semenjak dilahirkan manusia sudah mempunyai naluri untuk hidup berkawan sehingga dia disebut social animal. Sebagai social animal manusia mempunyai naluri yang disebut gregariousness. Pada hubungan antara manusia dengan sesamanya, agaknya yang penting adalah reaksi yang timbul sebagai akibat adanya hubungan tadi. Reaksi-reaksi itu mengakibatkan bertambah luasnya sikap tindak seseorang. Menteri Yohana menambahkan bahwa jajaran kementeriannya telah membangun upaya strategis memerangi Kekerasan Dalam Rumah Tanggga di Indonesia. Kementerian Pemberdayaan Perempuan dan Perlindungan Anak Republik Indonesia membuat beragam regulasi yang melindungi perempuan dan anak dari Kekerasan dalam Rumah Tangga yang berakar dari konvensi global mengenai pencegahan kekerasan domestik.

Ia juga menengarai pentingnya keluarga sebagai fondasi utama mencegah Kekerasan dalam Rumah Tangga. Hanya saja, dengan belum adanya kementerian 
yang khusus menangani keluarga, pihaknya terus melakukan koordinasi dengan beragam kementerian dan lembaga negara yang mengurus berbagai aspek dalam keluarga seperti aspek sosial, kesehatan, dan ekonomi. Ia juga berharap bahwa peraturan daerah (Perda) yang mengatur mengenai ketahanan keluarga pada beberapa provinsi dapat diadopsi oleh provinsi-provinsi lainnya di Indonesia untuk dapat diterapkan.Dalam rangka menanggulangi terjadinya Kekerasan dalam Rumah Tangga, Yohana berpesan bahwa negara melindungi segenap warganya dari setiap kekerasan tanpa diskriminasi. Ia juga berharap agar setiap elemen masyarakat menyadari betapa strategisnya posisi perempuan dan anak-anak dalam masyarakat Indonesia sehingga kejadian Kekerasan dalam Rumah Tangga dapat diminimalisir. ${ }^{1}$

Saat seorang istri mengalami kekerasan dari suami, mereka jarang melaporkan suaminya ke polisi. Bahkan ketika peraturan mengenai Kekerasan dalam Rumah Tangga yang termaktub dalam Undang-Undang Nomor 23 Tahun 2004 tentang Penghapusan Kekeran dalam Rumah Tangga, sebagian besar perempuan lainnya lebih memilih untuk menempuh jalan damai atau mediasi karena para perempuan ini masih memiliki ketergantungan ekonomi dan psikis pada pelaku (pasangan). Keterbatasan ekonomi dan kebutuhan untuk dilindungi serta disayang orang lain (pasangan), adalah penyebab utama keengganan para korban melaporkan pelaku Kekerasan dalam Rumah Tangga. Meskipun kekerasan yang dialami terkadang tergolong dalam Kekerasan dalam Rumah Tangga berat, korban tidak ingin pelaku dihukum atau dipenjara. Mereka hanya berharap pelaku dapat mengubah perilakunya tersebut. Dari sini, tak jarang korban baru menempuh proses pidana saat kekerasan benar-benar sudah berat dan berulangkali terjadi. Sedangkan bagi korban yang mengalami Kekerasan dalam Rumah Tangga dan memperkarakannya ke hukum pidana, jumlahnya lebih kecil lagi. Dengan demikian, perempuan sebagai pihak yang hampir selalu menjadi korban Kekerasan dalam Rumah Tangga, menemui beban berlapis yang datang dari luar dan diri sendiri. Yakni kerap dilempar kesalahan oleh masyarakat atau keluarga, 2012, hal.23.

${ }^{1}$ Soerjono Soekanto, Sosiologi Suatu Pengantar, PT. Raja Grafindo Persada, Jakarta, 
serta masih sangat bergantung secara ekonomi dan psikis terhadap pelaku Kekerasan dalam Rumah Tangga. Tetapi anggapan mengenai hal tersebut belum semuanya benar, karena sekarang ini banyak sekali terjadi tindakan Kekerasan dalam Rumah Tangga.

Tindak Kekerasan dalam Rumah Tangga sebenarnya bukan suatu hal yang baru, Kekerasan sering dilakukan bersamaan dengan salah satu bentuk tindak pidana, tindak kekerasan dapat dilakukan dengan kekerasan atau ancaman kekerasan dilakukan atau alat apa yang dipakai, masing-masing tergantung pada kasus yang timbul. Perbuatan tersebut dapat menimpa siapa saja, baik laki-laki maupun perempuan, dari anak-anak sampai dengan dewasa, apalagi kalau kekerasan terjadi dalam ruang lingkup rumah tangga, seringkali tindak kekerasan ini disebut hidden crime (kejahatan yang tersembunyi) disebut demikian, karena baik pelaku maupun korban berusaha untuk merahasiakan perbuatan tersebut dari pandangan publik. $^{2}$

Secara hukum yang dimaksud dengan Kekerasan dalam Rumah Tangga adalah setiap perbuatan terhadap seseorang terutama perempuan, yang berakibat timbulnya kesengsaraan atau penderitaan secara fisik, seksual, psikologis, dan/atau penelantaran rumah tangga termasuk ancaman untuk melakukan perbuatan, pemaksaan, atau perampasan kemerdekaan secara melawan hukum dalam lingkup rumah tangga.

Penyebab utama terjadinya Kekerasan dalam Rumah Tangga bertitik pada tidak adanya kesetaraan dalam keluarga. Pelaku Kekerasan dalam Rumah Tangga pun, tidak dapat dipukul rata karena jenjang pendidikan yang tinggi maupun rendah. Usia berapapun dalam pernikahan dapat menjadi pelaku utama Kekerasan dalam Rumah Tangga. Status ekonomi maupun sosial juga tidak berpengaruh untuk tidak melakukan Kekerasan dalam Rumah Tangga. Dari Pejabat sampai rakyat semua berpotensi untuk dapat melakukan Kekerasan dalam Rumah Tangga. Juga Agama, maupun ras. Sehingga dapat kita ambil kesimpulan bahwa kejahatan ini terjadi akibat tidak adanya kesetaraan dalam rumah tangga.

\footnotetext{
${ }^{2}$ Ahmad thahir, Hukum dalam Rumah Tangga, Internusa Press, Jakarta, 2014, hal. 20.
} 
Cara yang lain misalnya ketika suami melarang istri dalam bekerja atau sebaliknya. Hal ini menyebabkan istri memiliki ketergantungan seacara ekonomi pada pasangan. Itu sudah masuk Kekerasan dalam Rumah Tangga atau seorang istri dipaksa bekerja untuk memenuhi kebutuhan sendiri tanpa diberikan nafkah oleh suami. Itu merupakan Kekerasan dalam Rumah Tangga. ${ }^{3}$

Kekerasan dalam Rumah Tangga merupakan sebuah persoalan serius, karena di dalam rumah tanggalah kehidupan setiap manusia dimulai. Kekerasan dalam Rumah Tangga bisa disebabkan oleh faktor internal dan eksternal, baik itu secara perseorangan maupun secara bersama-sama.

Keutuhan dan kerukunan rumah tangga dapat terganggu jika kualitas dan pengendalian diri tidak dapat dikontrol, yang pada akhirnya dapat terjadi Kekerasan dalam Rumah Tangga sehingga timbul ketidakamanan atau ketidakadilan terhadap orang yang berada dalam lingkup rumah tangga tersebut. Aparat kepolisian sebagai penegak hukum mempunyai tugas yang berat untuk menangani suatu tindak pidana yang ada terutama Kekerasan dalam Rumah Tangga dan tindakan kekerasan yang terjadi di suatu wilayah terkait erat dengan situasi dan kondisi sosial, ekonomi, politik, dan budaya masyarakatnya.

Ada kesenjangan antara Undang - Undang Nomor 23 Tahun 2004 tentang Penghapusan Kekerasan dalam Rumah Tangga dengan sesuatu yang terjadi dimasyarakat karena enggan melaporkan bahkan sudah diproses di Pengadilan pun divonis bebas. ${ }^{4}$

Berdasarkan uraian diatas, permasalahan yang akan diambil dalam penulisan artikel ini adalah "PERLINDUNGAN HUKUM TERHADAP KORBAN TINDAK PIDANA KEKERASAN DALAM RUMAH TANGGA YANG MENGAKIBATKAN LUKA BERAT (PUTUSAN NOMOR: 992 K/PID.SUS/2017)”.

\footnotetext{
${ }^{3}$ Badriyah Khaleed, S.H., Penyelesaian Hukum Kekerasan dalam Rumah Tangga Penghapusan Kekerasan dalam Rumah Tangga dan Upaya Pemulihannya, Yogyakarta, 2015, hal.12.

${ }^{4}$ Barda Nawawi Arief, Masalah Penegakan Hukum dan Kebijakan Hukum Pidana Dalam Penanggulangan Kejahatan, Kencana Prenada Media Group, Jakarta, 2010, hal. 55.
} 


\section{B. Hasil Penelitian dan Pembahasan}

\section{PERLINDUNGAN HUKUM TERHADAP KORBAN KEKERASAN} DALAM RUMAH TANGGA

\section{A. Undang-Undang Nomor 23 tahun 2004 tentang Penghapusan kekerasan Dalam Rumah Tangga}

Dalam kekerasan dalam rumah tangga terdapat juga hal-hal yang mengatur tentang hak korban. Pasal ini menerangkan, bahwa korban KDRT berhak mendapatkan perlindungan, pelayanan, dan pendampingan secara khusus dari setiap instansi terkait maupun masyarakat sekitar yang mengetahui kasus KDRT tersebut. Diantaranya kepolisisan, Instansi Sosial, Pengadilan dan lembaga hukum lainnya yang terkait masalah tersebut. Perlindungan kepada korban diberikan $1 \mathrm{x}$ 24 jam terhitung sejak mengetahui dan menerima laporan, kepolisisan memberikan perlindungan pada korban atas dasar surat izin dari pengadilan.

Walapun kepolisian hanya memberikan perlindungan sementara selama 7 hari. Ketika dalam masa perlindungan kepolisian tidak hanya melindungi, tapi membimbing korban dengan bimbingan rohani, bekerja sama dengan instansi social yang tersedia. ${ }^{5}$

Disamping itu polisi pun wajib memberikan pengertian tentang hak-hak yang mesti diterima oleh korban dalam pelayanan dan pendampingan. Selain dari itu polisi atau petugas wajib memberikan identitasnya kepada korban, karena korban mesti mengetahui dengan jelas siapa dari pihak polisi yang memberikan pelayanan dan pendampingan. Dalam rangka memberikan rasa aman bagi korban.Sarana kesehatan yang tersedia baik itu milik masyarakat, pemerintah daerah atau pemerintah, harus menunjang kelangsungan pemeriksaan kesehatan kepada korban dengan standar profesinya. Jika Visum ingin dilakukan, maka

${ }^{5}$ https://zirscorp.wordpress.com/2019/02/28/hak-korban-kdrt-dari-pemerintah-danmasyarakat/diakses tanggal 28 Juni 2021 
harus disertai dengan persetujuan/permintaan dari keluarga korban, dengan dasar mencari alat bukti.

Psikologis dan fisik korban dilindungi, salah satunya dengan memberi tahukan korban hak-haknya selaa dalam perlindungan agar dapat merasa terlidungi dan aman. Lebih jauhnya koban dikuatkan baik dari psikologis dan fisiknya. Arahan dari bidang rohani kepada korban adalah memberikan penguatan iman dan taqwa kepada korban. Advokat mendampingi korban selama dia berususan dengan hokum terkait undang-undang KDRT dan memberikan pejelasan kepada korban, tentang hal yang akan dihadapinya baik dalam persidangan dan lain-lain. Korban dapat melaporkan secara langsung ataupun diberikan kepada kuasa hukumnya baik di kalangan keluarga ataupun kerabat yang lainnya. Jika korban adlah seorang anak maka dia berhak melaporkannya melalui wali, orang tua, pengasuh atau anak yang bersangkutan yang disusun dalam undang-undang yang berlaku. Dalam keadaaan tertentu pemohon dapat mengajukan tanpa persetujuan korban.

Hak-Hak Korban KDRT telah diatur dalam Undang-Undang Nomor 23 Tahun 2004 Tentang Penghapusan Kekerasan Dalam Rumah Tangga secara jelas bahwa :

1. Perlindungan dari pihak keluarga, kepolisian, kejaksaan, pengadilan,advokat, lembaga social, atau pihak lainnya baik sementara maupun berdasarkan penetapan perintah perlindungan dari pengadilan

2. Pelayanan kesehatan sesuai dengan kebutuhan medis

3. Penanganan secara khusus berkaitan dengan kerahisaan korban

4. Pendampingan oleh pekerja sosial dan bantuan hukum pada tingkat proses pemeriksaan sesuai dengan ketentuan peraturan perundang-undangan.

5. Pelayanan bimbingan rohani. ${ }^{6}$

\section{B. Peraturan Pemerintah Nomor 4 tahun 2006 tentang Penyelenggaraan dan Kerja Sama Pemulihan Korban Kekerasan Dalam Rumah Tangga} 2011,hal.116.

${ }^{6}$ Moerti Hadiati soeroso, Kekerasan Dalam Rumah Tangga, Jakarta: Sinar grafika, 
Dalam perkembangannya perlindungan terhadap korban kekerasan dalam rumah tangga semakin ditingkatkan oleh pemerintah karena banyaknya kasus yang terjadi dan kurang diperhatikannya korban.Hal ini membuat Pemerintah menetapkan sebuah Undang-undang yang diharapkan mampu membantu dan memperhatikan korban yang selama ini kurang diperhatikan.

Upaya pemulihan korban kekerasan dalam rumah tangga merupakan amanat dari Pasal 43 Undang-undang Nomor 23 Tahun 2004 Tentang Penghapusan Kekerasan Dalam Rumah Tangga. Untuk menunjang pelaksanaan tersebut, perlu pengaturan mengenai penyelenggaran dan kerjasama pemulihan korban dengan menentukan tugas dan fungsi masing-masing dan kewajiban serta tanggung jawab tenaga kesehatan, pekerja sosial, pembimbing rohani, dan relawan pendamping. Untuk lebih mengefektifkan pelayanaan terpadu, maka dalam peraturan ini dibentuk forum koordinasi yang akan mengkoordinasikan antar petugas pelayanan, sekaligus menyusun rencana program bagi peningkatan upaya pemulihan korban kekerasan dalam rumah tangga. Forum koordinasi tersebut dibentuk dipusat dan didaerah. Menteri membentuk forum koordinasi di tingkat pusat, sedangkan ditingkat daerah dibentuk oleh gubernur.

Penyelenggaran kerjasama pemulihan korban kekerasan dalam rumah tangga diarahkan pada pulihnya kondisi korban seperti semula baik secara fisik maupun psikis dalam waktu yang tidak terlalu lama, sehingga korban dapat menjalankan aktivitasnya sehari-hari dan dapat hidup di masyarakat seperti semula. Oleh karena itu, pelayanan harus dilakukan semaksimal mungkin segera setelah adanya pengaduan atau pelaporan dari korban untuk memperoleh pelayanaan bagi pemulihan kondisi korban kekerasan dalam rumah tangga. Upaya bertujuan menjamin terlaksananya kemudahan pelayanan korban kekerasan dalam rumah tangga, penyelenggaraan pemulihan korban kekerasan dalam rumah tangga pada dasarnya menjamin efektivitas dan efisiensi bagi proses pemulihan korban kekerasan dalam rumah tangga dan tercipta kerjasama dan koordinasi yang baik dalam pemulihan korban kekerasan dalam rumah tangga antar instansi, antar petugas pelaksanaan dan antar lembaga terkait lainnya. 
Lingkup kekerasan dalam rumah tangga adalah perbuatan terhadap seseorang terutama perempuan, yang berakibat timbulnya kesengsaraan atau penderitaan secara fisik, seksual, psikologis, dan/atau penelantaran rumah tangga termasuk ancaman untuk melakukan perbuatan, pemaksaan, atau perampasan kemerdekaan secara melawan hukum dalam lingkup rumah tangga. Sebagian besar korban kekerasan dalam rumah tangga adalah kaum perempuan (istri) dan pelakunya adalah suami, walaupun ada juga korban justru sebaliknya, atau orangorang yang tersubordinasi di dalam rumah tangga itu. Pelaku atau korban kekerasan dalam rumah tangga adalah orang yang mempunyai hubungan darah, perkawinan, persusuan, pengasuhan, perwalian dengan suami, dan anak bahkan pembatu rumah tangga yang tinggal dalam sebuah rumah tangga. Tidak semua tindakan kekerasan dalam rumah tangga dapat ditangani secara tuntas karena korban sering menutup-nutupi dengan alasan ikatan struktur budaya, agama, dan belum dipahaminya sistem hukum yang berlaku. Padahal perlindungan oleh negara dan masyarakat bertujuan untuk memberi rasa aman terhadap korban serta menindak pelakunya.

Pemerintah sebagai instansi yang mempunyai tugas dan fungsi sebagai penyrelenggara pemulihan korban kekerasan dalam rumah tangga wajib memberikan fasilitas kepada korban kekerasan dalam rumah tangga meliputi:

1. Ruang pelayanan khusus di jajaran kepolisian;

2. Tenaga yang ahli dan professional;

3. Pusat pelayanan dan rumah aman;dan

4. Sarana dan prasarana lain yang diperlukan untuk pemulihan korban.

Pada Pasal 4 dan Pasal 5 PP Nomor 4 Tahun 2006 mengatur kegiatan yang dilakukan dalam hal penyelenggaraan pemulihan korban berupa:

1. Pelayanan kesehatan

Pelayan kesehatan dilakukan oleh tenaga kesehatan di sarana kesehatan milik pemerintah, pemerintah daerah, dan masyarakat, termasuk swasta dengan cara memberikan pelayanan pengobatan dan pemulihan kesehatan korban.

2. Pendampingan korban 
Pendampingan korban dilakukan oleh tenaga kesehatan, pekerja sosial, relawan pendamping, dan/atau pembimbing rohani dengan cara memberikan konseling, terapi, bimbingan rohani dan advokasi guna penguatan dan pemulihan korban.

3. Pemberian konseling

Pemberian konseling dilakukan oleh pekerja sosial, relawan pendamping, dengan mendengarkan secara empati dan menggali permasalahan untuk penguatan psikologis korban.

4. Bimbingan rohani

Bimbingan rohani dilakukan oleh pembimbing rohani dengan cara memberikan penjelasan mengenai hak dan kewajibannya, serta penguatan iman dan takwa sesuai dengan agama dan kepercayaan yang dianutnya.

5. Resosialisasi korban

Resosialisasi korban dilaksanakan oleh instansi sosial dan lembaga sosial agar korban dapat kembali melaksanakan fungsi sosialnya dalam masyarakat.Untuk kepentingan pemulihan korban yang mengalami kekerasan fisik, korban berhak mendapatkan pelayanan dari tenaga kesehatan yang berupa pengobatan dan pemulihan kesehatan sesuai dengan standar profesi, standar prosedur operasional, dan kebutuhan medis korban. Pelayanan pemulihan kesehatan dapat dilakukan di sarana kesehatan dasar, sarana kesehatan rujukan milik pemerintah maupun milik swasta. Dalam memberikan pelayanan kepada korban, tenaga kesehatan melakukan upaya:
a. Anamnesis kepada korban;
b. Pemeriksaan kepada korban;
c. Pengobatan penyakit;
d. Pemulihan kesehatan, baik fisik maupun psikis;
e. Konseling; dan/atau
f. Merujuk ke sarana kesehatan lebih memadai bila diperlukan.

Selain upaya tersebut di atas, khususnya untuk kasus tertentu seperti pemerkosaan, tenaga kesehatan juga memberikan pelayanan keluarga berencana 
darurat dan pelayanan reproduksi lainnya sesuai dengan kebutuhan medis. Tenaga kesehatan juga harus membuat rekam medis sesuai dengan ketentuan peraturan perundang-undangan. Untuk kepentingan penyidikan, tenaga kesehatan yang berwenang harus membuat "visum et repertum" atau membuat surat keterangan medis.

Pekerja sosial dalam memberikan pelayanan kepada korban kekerasan dalam rumah tangga, dapat dilakukan di rumah aman, pusat pelayanan atau tempat tinggal alternatif milik pemerintah, pemerintah daerah, atau masyarakat. Dalam memberikan pelayanan pemulihan harus dengan persetujuan korban, korban dapat ditempatkan oleh pekerja sosial di rumah aman, pusat pelayanan, atau tempat tinggal alternatif yang aman untuk melindungi korban dari ancaman. Pengadaan rumah aman, pusat pelayanan, atau tempat tinggal alternatif yang dilakukan masyarakat dapat difasilitasi oleh pemerintah dan/atau pemerintah daerah sesuai dengan ketentuan peraturan perundang-undangan.

Beberapa upaya yang dilakukan oleh penyelenggara kegiatan pemulihan korban kekerasan dalam rumat tangga yaitu:

1. Upaya yang harus dilakukan pekerja sosial dalam memberikan pelayanan pemulihan kepada korban, yaitu berupa:

a. Menggali permasalahan korban untuk membantu pemecahan masalah;

b. Memulihkan korban dari kondisi traumatis melalui terapi psikososial;

c. Melakukan rujukan rumah sakit atau rumah aman atau pusat pelayanan atau tempat alternatiflainnya sesuai dengan kebutuhan korban;

d. Mendampingi korban dalam upaya pemulihan melalui pendampingan konseling; dan/atau

e. Melakukan resosialisasi agar korban dapat kembali melaksanakan fungsi sosialnya di dalam masyarakat.

Selain upaya di atas untuk mempermudah dalam memproses pelaksanaan pelayanan pemulihan korban juga dilakukan upaya pendampingan, yaitu sebagai berikut: 
a. Membangun hubungan yang setara dengan korban agar bersedia membuka diri dalam mengemukakan persoalannya;

b. Berempati dan tidak menyalahkan korban mengenai atau yang berkaitan dengan permasalahannya;

c. Menyakinkan korban bahwa tidak seorang pun boleh melakukan tindakan kekerasan;

d. Menanyakan apa yang ingin dilakukan dan bantuan apa yang diperlukan;

e. Memberikan informasi dan menghubungkan dengan lembaga atau perorangan yang dapat membantu mengatasi persoalannya; dan/atau

f. Membantu memberikan informasi tentang layanan konsultasi hukum.

2. Upaya yang harus dilakukan pembimbing rohani dalam memberikan pelayanan pemulihan kepada korban, yaitu berupa:

a. Menggali informasi dan mendengarkan keluh kesah dari korban;

b. Mempertebal keimanan dan ketakwaan korban serta mendorong untuk mejalankan ibadat menurut agama dan kepercayaan masing-masing korban;

c. Menyarankan pemecahan masalah kekerasan dalam rumah tangga menurut agama dan kepercayaan masing-masing korban;

d. Memberikan pemahaman mengani kesetaraan laki-laki dan perempuan.

Pemerintah daerah untuk melakukan pemulihan korban dapat melakukan kerjasama antar instansi terkait dengan masyarakat yang peduli terhadap penghapusan kekerasan dalam rumah tangga. Kerjasama dilakukan oleh suatu badan yang khusus mendampingi pemberdayaan perempuan dan anak. Dalam hal tertentu, tenaga kesehatan, pekerja sosial, relawan pendamping dan/atau pembimbing rohani dapat menjalin kerjasama dengan:

1. Kepolisian, untuk melaporkan dan memperoses pelaku tindak pidana kekerasan dalam rumah tangga;

2. Advokat, untuk membantu korban dalam proses peradilan;

3. Penegak hukum lainnya, untuk membantu korban dalam proses di sidang pengadilan; 


\section{Komisi Nasional Anti Kekerasan Terhadap Perempuan;}

5. Komisi Perlindungan Anak Indonesia (KPAI);

6. Pihak tertentu yang diinginkan demi kepentingan korban.

Pasal 22 PP Nomor 4 Tahun 2006 menetapakan bahwa segala biaya untuk pelaksanaan pemulihan yang dilakukan oleh pemerintah dan pemerintah daerah terhadap korban kekerasan dalam rumah tangga dibebankan pada:

1. Anggaran Pendapatan Belanja Negara (APBN);

2. Anggaran Pendapatan Belanja Daerah (APBD); dan

3. Sumber pendapatan lain yang yang sah perolehannya sesuai dengan peraturan perundang-undangan.

Pemulihan perempuan korban kekerasan harus dapat dimaknai secara luas,tidak saja intervensi yang dilakukan secara medis, hukum, maupun psikososial, tetapi juga penciptaan situasi dimana perempuan korban kekerasan dapat kembali bentuknya secara utuh, sehingga mampu mengambil keputusankeputusan dalam hidupnya dan bisa kembali menjalankan perannya ditengah masyarakat sebagai perempuan dan warga. Tindakan ini tidak saja menuntut keseriusan negara selaku pemikul tanggung jawab, namun juga menghendaki adanya dukungan dan keterlibatan dari masyarakat dan keluarga. ${ }^{7}$

Upaya pemberian layanan dengan memadukan berbagai disiplin telah dikembangkan oleh berbagai pihak, namun kecenderungan untuk menyikapi layanan secara sebagian (parsial) tetap saja terjadi, padahal untuk kembali berdaya dibutuhkan paduan multi disiplin dengan pendekatan yang holistik. Tantangan pertama dalam memberikan pemulihan adalah, bagaimana agar korban tidak semakin merasa tertekan atau mengalami reviktimasi ( kekerasan yang berulang). Langkah penting untuk mencegah ini dengan menbangun kerjasama yang saling melengkapi antar penyelenggara layanan dalam memberikan pelayanan kepada korban sesuai dengan kebutuhan dan pilihannya. Kerjasama berarti mampu melakukan koordinasi serta pembagian kerja yang jelas dan realistis antar

\footnotetext{
${ }^{7}$ Heni Hendrawati dan Agna Susila, Kajian Yuridis PP No 4 Tahun 2006 Tentang Penyelenggaraan dan Pemulihan Korban Kekerasan Dalam Rumah Tangga, Fakultas Hukum Universitas Muhammadiyah Magelang,Jurnal Hukum Vol 13 No.2, Oktober 2017, hal. 120
} 
lembaga, termasuk kesiapan mekanisme yang disepakati bersama dan didukung oleh kebijakan serta sumber daya yang memadai. Di sisi lain negara berkewajiban menyediakan anggaran yang cukup untuk penanganan perempuan korban kekerasan.

Melalui Sub Komisi Pemulihan,Komnas Perempuan mencoba menjembatani sinergisitas antara negara dan masyarakat dalam mengembangkan sistem pemulihan yang menyeluruh dan bermakna luas bagi perempuan korban kekerasan. Komnas Perempuan tidak hanya memfasilitasi dialog kebijakan dan mengembangkan sistem layanan yang berpihak kepada korban, tetapi juga mendorong lahirnya kebijakan yang berpihak pada pemenuhan hak korban dan membantu organisasi pengada layanan untuk meningkatkan kapasitasnya dalam memberikan layanan bagi perempuan korban kekerasan dalam rumah tangga. ${ }^{8}$

Dengan lahirnya Undang-undang ini diharapkan perhatian terhadap korban kekerasan dalam rumah tangga semakin diperhatikan sehingga tidak menimbulkan trauma yang berkelanjutan terhadap korban yang selama ini kerap ditemui dalam setiap kasu yang terjadi di Indonesia.Undang-undang ini diharapkan juga sebagai pedoman yang harus diikuti semua pihak yang terlibat sehingga penggunaannya yang efisien dan ditaati.

Peran semua lembaga yang berkaitan sangat diharapkan dalam penegakan hukum yang adil bagi korban yang selama ini para korban kurang diperhatikan karena pemerintah cenderung lebih memperhatikan hukuman bagi pelaku tanpa ada bantuan terhadap para korban yang sebenarnya merupakan titik utama yang harus dibantu .

Amanat dari Pasal 43 Undang -Undang Nomor 23 tahun 2004 Tentang Penghapusan kekerasan Dalam rumah Tangga adalah adanya upaya Pemulihan korban kekerasan dalam rumah tangga antara pemerintah dan masyarakat. Adanya Peraturan Pemerintah ini adalah sebagai upaya untuk memulihkan kondisi korban kekerasan seperti kondisi fisik,psikis dalam waktu yang tidak terlalu lama.Fasilitas pelayanan yang dilaksanakan pemerintah dan lembaga sosial

${ }^{8}$ Ibid, hal. 121 
meliputu ruang pelayanan khusus dijajaran kepolisian ,tenaga ahli,dan professional, pusat pelayanan dan ruang aman, dan sarana prasarana lain yang diperlukan untuk pemulihan korban.

Bentuk kerja sama pemulihan yang bisa dilakukan menurut Peraturan Pemerintah ini termasuk kerja sama dengan lembaga sosial yang mengurusi korban kekerasan dalam rumah tangga,tenaga kesehatan,pekerja sosial, relawan,dan pendamping rohani.Peraturan Pemerintah ini juga mengatur tentang pembiayaan pelaksanaan pemulihan. Lahirnya Peraturan ini tentunya menandakan semakin diperhatikannya nasib korban keekerasan oleh pemerintah yang selama ini dikesampingkan.Hal ini sangat menjamin keselamatan para korban setelah adanya kekerasan sehingga diharapkan dapat sembuh.

\section{PERTIMBANGAN HUKUM HAKIM DALAM MENJATUHKAN PUTUSAN TERHADAP KASUS TINDAK PIDANA KEKERASAN DALAM RUMAH TANGGA YANG MENGAKIBATKAN LUKA BERAT PADA PERKARA NOMOR: 992 K/PID.SUS/2017}

\section{A. Penerapan Hukum Pidana Materiil Putusan Mahkamah Agung Nomor: 992 K/PID.SUS/2017}

\section{Kasus Posisi}

Bahwa Terdakwa NOVI TRIONO alias NOPE bin ISHAK MARIM pada hari Senin tanggal 01 Agustus 2016 sekira pukul 14.00 WIB atau pada waktu lain tahun 2016 bertempat di Warung Makan Lesada Dusun Lodadi Umbulmartani Ngemplak Kabupaten Sleman atau pada tempat lain yang termasuk dalam daerah hukum Pengadilan Negeri Sleman, melakukan penganiayaan mengakibatkan luka berat, perbuatan Terdakwa dilakukan dengan cara-cara sebagai berikut: Bahwa bermula Terdakwa NOVI TRIONO alias NOPE bin ISHAK MARIM pada hari Senin tanggal 01 Agustus 2016 sekira pukul 11.00 WIB masuk ke dalam kamar kos WARSONO RAKA SIWI lalu Terdakwa menemukan barang-barang pribadi milik istri Terdakwa yang bernama saksi SRI ASTUTI SUDARSIH, lalu Terdakwa menemui saksi SRI ASTUTI SUDARSIH di Warung Makan Lesada di 
Dusun Lodadi Umbulmartani Ngemplak Sleman, selanjutnya ketika Terdakwa melihat saksi WARSONO RAKA SIWI langsung emosi lalu mengambil pisau gobang (pisau besar), selanjutnya Terdakwa mengarahkan pisau gobang yang dipegang dengan tangan kanan Terdakwa ke arah saksi WARSONO RAKA SIWI hingga mengenai saksi WARSONO RAKA SIWI pada bagian leher, kepala bagian kiri, paha, pundak.

Bahwa selanjutnya saksi SRI ASTUTI SUDARSIH pasang badan / menghalangi Terdakwa agar tidak menganiaya saksi WARSONO RAKA SIWI, lalu Terdakwa terus mengarahkan pisau gobang untuk menganiaya WARSONO RAKA SIWI hingga mengenai saksi SRI ASTUTI SUDARSIH pada bagian lengan tangan kiri, punggung dan jari saksi SRI ASTUTI SUDARSIH hingga mengeluarkan darah.

Bahwa akibat perbuatan Terdakwa berdasarkan Visum et Repertum tanggal 21 Agustus 2016 atas nama WARSONO RAKA SIWI, yang dibuat dan ditandatangani oleh dr. Sesarius Bimo W, dokter pada Rumah Sakit Panti Nugroho dengan pemeriksaan khusus : pada lengan kanan tampak luka robek +4 $\mathrm{cm}$, pada pipi kiri tampak luka robek $+6 \mathrm{~cm}$, pada bagian temporupanetal kiri luka robek $+7 \mathrm{~cm}$, pada paha kiri luka robek sampai lapisan otot $+4 \mathrm{~cm}$, pada punggung tangan kanan tampak luka robek $+4 \mathrm{~cm}$, luka lecet dibahu $9 \mathrm{~cm}$ dan 6 $\mathrm{cm}$, leher belakang $9 \mathrm{~cm}$, bahu kanan belakang 9 X $3 \mathrm{~cm}$, leher depan $12 \mathrm{~cm}, 6 \mathrm{~cm}$ dan $10 \mathrm{~cm}$, kesimpulan : perlukaan akibat kekerasan benda tajam;

Bahwa akibat perbuatan Terdakwa berdasarkan Visum et Repertum tanggal 21 Agustus 2016 atas nama SRI ASTUTI SUDARSIH, yang dibuat dan ditandatangani oleh dr. Sesarius Bimo W, dokter pada Rumah Sakit Panti Nugroho dengan pemeriksaan khusus : pada lengan bawah kiri tampak luka robek sampai lapisan otot ukuran kurang lebih $4 \mathrm{~cm}$ dan pada punggung bagian kanan tampak luka robek kurang lebih $3 \mathrm{~cm}$ kesimpulan : perlukaan akibat kekerasan benda tajam.

\section{Dakwaan Penuntut Umum}


Adapun isi dakwaan Penuntut Umum yang diajukan dalam kasus ini yakni yang dilakukan oleh Terdakwa NOVI TRIONO alias NOPE bin ISHAK MARIM adalah sebagai berikut :

a. Kesatu;

1) Dakwaan Primair

Perbuatan Terdakwa sebagaimana diatur dan diancam pidana dalam Pasal 351 Ayat (2) KUHP.

2) Dakwaan Subsidiair

Perbuatan Terdakwa sebagaimana diatur dan diancam pidana dalam Pasal 351 Ayat (1) KUHP.

b. Kedua;

1) Dakwaan Primair

Perbuatan Terdakwa sebagaimana diatur dan diancam pidana dalam Pasal 44 Ayat (2) Undang-Undang Nomor 23 Tahun 2004 tentang Penghapusan Kekerasan dalam Rumah Tangga.

\section{Tuntutan Jaksa Penuntut Umum}

Berdasarkan dari fakta-fakta yang ada dipersidangan, maka Jaksa Penuntut Umum dalam perkara ini pada pokoknya menuntut sebagai berikut :

1) Menyatakan Terdakwa NOVI TRIONO alias NOPE bin ISHAK MARIM bersalah melakukan tindak pidana "Penganiayaan yang mengakibatkan luka berat" sebagaimana diatur dan diancam pidana oleh Pasal 351 Ayat (2) KUHP dalam dakwaan Kesatu Primair dan melakukan tindak pidana "Kekerasan fisik dalam lingkup rumah tangga sebagaimana dimaksud dalam Pasal 5 Huruf a" sebagaimana diatur dan diancam pidana oleh Pasal 44 Ayat (1) Undang-Undang Nomor 23 Tahun 2004 tentang Penghapusan Kekerasan Dalam Rumah Tangga dalam dakwaan Kedua Subsidiair;

2) Menjatuhkan pidana terhadap Terdakwa NOVI TRIONO alias NOPE bin ISHAK MARIM tersebut berupa pidana penjara selama 2 (dua) tahun dengan dikurangi selama Terdakwa ditahan dan dengan perintah agar 
Terdakwa tetap ditahan, dan pidana denda sebesar Rp2.000.000,00 (dua juta rupiah) subsidiair 6 (enam) bulan kurungan;

3) Menyatakan barang bukti berupa:

- 1 (satu) buah pisau daging/gobang berukuran besar terbuat dari bahan stainless steel merek EAGLE panjang lk 30 (tiga puluh) $\mathrm{cm}$ lebar 10 (sepuluh) cm dengan gagang terbuat dari aluminium croom / silver;

Dirampas untuk dimusnahkan;

4) Menetapkan agar Terdakwa membayar biaya perkara sebesar Rp2.000,00 (dua ribu rupiah);

\section{Amar Putusan}

a. Putusan Pengadilan Tingkat Pertama (Putusan Pengadilan Negeri Sleman Nomor 472/Pid.Sus/2016/PN.Smn:

- Menyatakan Terdakwa NOVI TRIONO alias NOPE bin ISHAK MARIM tidak terbukti secara sah dan meyakinkan bersalah melakukan tindak pidana sebagaimana dalam dakwaan Kesatu Primair dan Kedua Primair;

- Membebaskan Terdakwa dari dakwaan Kesatu Primair dan Kedua Primair tersebut;

- Menyatakan Terdakwa telah terbukti secara sah dan meyakinkan bersalah melakukan tindak pidana Penganiayaan dan melakukan perbuatan kekerasan fisik dan dalam lingkup rumah tangga;

- Menjatuhkan pidana kepada Terdakwa oleh karena itu dengan pidana penjara selama 1 (satu) tahun;

- Menetapkan masa penangkapan dan penahanan yang telah dijalani oleh Terdakwa dikurangkan seluruhnya dari pidana yang dijatuhkan;

- Menetapkan agar Terdakwa tetap berada dalam tahanan;

- Menetapkan barang bukti berupa:

- 1 (satu) buah pisau daging/gobang berukuran besar terbuat dari bahan stainless steel merek EAGLE panjang lebih kurang 30 (tiga 
puluh) $\mathrm{cm}$ lebar 10 (sepuluh) $\mathrm{cm}$ dengan gagang terbuat dari alumunium croom / silver,

untuk dimusnahkan;

- Membebankan kepada Terdakwa untuk membayar biaya perkara sebesar Rp2.000,00 (dua ribu rupiah);

b. Putusan Tingkat Banding (Pengadilan Tinggi Yogyakarta Nomor 3/Pid.Sus/2017/PT YYK):

- Menerima permintaan banding dari Jaksa Penuntut Umum;

- Menguatkan Putusan Pengadilan Negeri Sleman tanggal 13 Desember 2016, Nomor 472/Pid.Sus/2016/PN.Smn yang dimintakan banding tersebut;

- Membebankan biaya perkara kepada Terdakwa dalam kedua tingkat peradilan, yang untuk tingkat banding sebesar Rp2.500,00 (dua ribu lima ratus rupiah);

c. Putusan Tingkat Kasasi (Mahkamah Agung Nomor: 992 K/PID.SUS/2017):

- Menolak permohonan kasasi dari Pemohon Kasasi / Penuntut Umum pada Kejaksaan Negeri Sleman tersebut;

- Membebankan kepada Terdakwa untuk membayar biaya perkara pada tingkat kasasi sebesar Rp2.500,00 (dua ribu lima ratus rupiah).

\section{B. Dasar Hukum dan Pertimbangan Hakim Mahkamah Agung} dalam memutus perkara Nomor: 992 K/PID.SUS/2017

Sebelum penulis menguraikan dasar hukum dan pertimbanganpertimbangan Hakim, perlu dipahami bahwa judex facti dalam hukum adalah Majelis Hakim di tingkat pertama yang wajib memeriksa bukti-bukti dari suatu kejadian perkara dan menerapkan aturan serta ketentuan hukum lainnya terhadap fakta-fakta dari perkara tersebut. Dengan kata lain, judex facti artinya adalah sistem peradilan dimana Majelis Hakim berperan sebagai penemu fakta mana yang benar. Putusan yang diambil dari sistem peradilan ini disebut Putusan Judex Facti dan Lembaga peradilan judex facti adalah Pengadilan Negeri dan Pengadilan Tinggi. 
Kasasi pada Mahkamah Agung merupakan ranah judex juris, dimana kasasi berarti pembatalan putusan oleh Mahkamah Agung apabila terdapat salah penerapan hukum atau Undang-Undang dalam Putusan Pengadilan Tinggi. Pengadilan kasasi adalah pengadilan yang memeriksa apakah judex facti tidak salah dalam melaksanakan peradilan. Upaya hukum kasasi adalah upaya agar putusan judex facti dibatalkan oleh Mahkamah Agung karena salah dalam melaksanakan peradilan. ${ }^{9}$

1. Dasar Hukum Hakim Mahkamah Agung dalam memutus perkara

Adapun Dasar Hukum Hakim Mahkamah Agung dalam memutus perkara Nomor: 992 K/PID.SUS/2017, Hakim merujuk dan memperhatikan:

a. Pasal 351 Ayat (1) Kitab Undang-Undang Hukum Pidana.

b. Pasal 44 Ayat (1) Undang-Undang Republik Indonesia Nomor 23 Tahun 2004 Tentang Penghapusan Kekerasan Dalam Rumah Tangga.

c. Kitab Undang-Undang Hukum Acara Pidana.

d. Undang-Undang Republik Indonesia Nomor 48 Tahun 2009 Tentang Kekuasaan Kehakiman.

2. Pertimbangan Hakim Mahkamah Agung dalam memutus perkara Adapun hal-hal yang dipertimbangkan oleh Hakim Mahkamah Agung sebelum memutus perkara Nomor: 992 K/PID.SUS/2017, sebagai berikut:

a. Hakim Mahkamah Agung mempertimbangkan Akta Permohonan Kasasi Nomor 5/Akta.Pid.Sus/2017/PN Smn yang dibuat oleh Panitera pada Pengadilan Negeri Sleman, yang menerangkan bahwa pada tanggal 27 Februari 2017 Penuntut Umum pada Kejaksaan Negeri Sleman mengajukan permohonan kasasi terhadap putusan Pengadilan Tinggi Yogyakarta tersebut.

b. Hakim Mahkamah Agung memperhatikan memori kasasi tanggal 8 Maret 2017 dari Penuntut Umum pada Kejaksaan Negeri Sleman sebagai Pemohon Kasasi, yang diterima di Kepaniteraan Pengadilan Negeri

${ }^{9}$ H. A. Mukti Arto, Praktek Perkara Perdata Pada Pengadilan Agama, Yogyakarta, Pustaka Pelajar, 2008, hal. 292. 
Sleman pada tanggal 13 Maret 2017 Membaca surat-surat yang bersangkutan.

c. Hakim Mahkamah Agung mempertimbangkan bahwa Putusan Pengadilan Tinggi Yogyakarta tersebut telah diberitahukan kepada Penuntut Umum pada Kejaksaan Negeri Sleman pada tanggal 20 Februari 2017 dan Penuntut Umum mengajukan permohonan kasasi pada tanggal 27 Februari 2017 serta memori kasasinya telah diterima di Kepaniteraan Pengadilan Negeri Sleman pada tanggal 13 Maret 2017, dengan demikian permohonan kasasi beserta dengan alasan-alasannya telah diajukan dalam tenggang waktu dan dengan cara menurut undang-undang, oleh karena itu permohonan kasasi Penuntut Umum tersebut formal dapat diterima;

d. Hakim Mahkamah Agung mempertimbangkan alasan permohonan kasasi yang diajukan oleh Pemohon Kasasi/Penuntut Umum pada pokoknya, sebagai berikut:

1) Bahwa Penuntut Umum sependapat dengan sebagian amar dari putusan Majelis Hakim Pengadilan Negeri Sleman yang dikuatkan oleh putusan Majelis Hakim Pengadilan Tinggi Yogyakarta, yang dalam hal menyatakan Terdakwa NOVI TRIONO alias NOPE bin ISHAK MARIM terbukti secara sah dan meyakinkan bersalah melakukan tindak pidana "kekerasan fisik dalam lingkup rumah tangga" sebagaimana dimaksud dalam Pasal 5 Huruf a" terhadap saksi korban SRI ASTUTI SUDARSIH sebagaimana dalam dakwaan Kedua Subsidiair.

2) Bahwa namun Pemohon Kasasi tidak sependapat dengan amar dari putusan Majelis Hakim Pengadilan Negeri Sleman yang dikuatkan oleh putusan Majelis Hakim Pengadilan Tinggi Yogyakarta dalam hal menyatakan Terdakwa NOVI TRIONO alias NOPE bin ISHAK MARIM terbukti secara sah dan meyakinkan bersalah melakukan tindak pidana "penganiayaan" terhadap saksi korban WARSONO RAKA SIWI sebagaimana dalam dakwaan Kesatu Subsidiair, karena 
sudah jelas bahwa luka yang didertita oleh saksi korban saksi

WARSONO RAKA SIWI adalah termasuk dalam pengertian luka berat sebagaimana diatur dalam Pasal 90 KUHP yaitu yang dimaksud dengan luka berat adalah "jatuh sakit atau mendapat luka yang tidak memberi harapan akan sembuh sama sekali atau yang menimbulkan bahaya maut";

3) Berdasarkan Visum et Repertum tertanggal 21 Agustus 2016 atas nama WARSONO RAKA SIWI, yang dibuat dan ditandatangani oleh dr. Sesarius Bimo W, dokter pada Rumah Sakit Panti Nugroho dengan pemeriksaan khusus: pada lengan kanan tampak luka robek $+4 \mathrm{~cm}$, pada pipi kiri tampak luka robek tampak luka robek $+6 \mathrm{~cm}$, pada bagian temporupanetal kiri luka robek $+7 \mathrm{~cm}$, pada paha kiri luka robek sampai lapisan otot $+4 \mathrm{~cm}$, pada punggung tangan kanan tampak luka robek + luka lecet dibahu $9 \mathrm{~cm}$ dan $6 \mathrm{~cm}$, leher belakang $9 \mathrm{~cm}$, bahu kanan belakang 9X3 cm, leher depan $12 \mathrm{~cm}, 6 \mathrm{~cm}$ dan 10 cm, kesimpulan: perlukaan akibat kekerasan benda tajam;

4) Berdasarkan visum et Repertum terhadap saksi korban WARSONO RAKA SIWI tersebut di atas terdapat luka pada bagian vital saksi korban yaitu pada leher belakang, leher depan dan pada pipi korban, di mana luka karena bacokan pisau daging Terdakwa tersebut bisa menimbulkan bahaya maut terhadap korban WARSONO;

5) Sehingga menurut Pemohon Kasasi yang seharusnya terbukti adalah dakwaan Kesatu Primair yaitu Terdakwa NOVI TRIONO alias NOPE bin ISHAK MARIM melakukan tindak pidana penganiayaan berat sebagaimana diatur dan diancam pidana dalam Pasal 351 Ayat (2) KUHP;

6) Bahwa dengan demikian Majelis Hakim telah salah atau keliru menafsirkan unsur luka berat dalam Pasal 351 Ayat (2) KUHP sebagaimana dalam pertimbangan Putusan Pengadilan Negeri Sleman di Sleman Nomor 472/Pid.Sus/2016/PN.Smn tanggal 13 Desember 
2016 pada halaman 20 menyatakan bahwa "Menimbang, bahwa berdasarkan pertimbangan tersebut Majelis Hakim berpendapat bahwa unsur penganiayaan yang mengakibatkan luka berat tidak terpenuhi”, sehingga dalam amar putusannya membebaskan Terdakwa NOVI TRIONO alias NOPE bin ISHAK MARIM dari dakwaan Kesatu Primair;

7) Bahwa Penuntut Umum juga tidak sependapat dalam amar putusan Majelis Hakim Pengadilan Negeri Sleman yang dikuatkan oleh putusan Majelis Hakim Pengadilan Tinggi Yogyakarta yang berbunyi "Menjatuhkan pidana kepada Terdakwa oleh karena itu dengan pidana penjara selama 1 (satu) tahun" tanpa dikenai pidana denda, karena pidana tersebut menurut Pemohon Kasasi terlalu ringan bagi Terdakwa jika dibandingkan dengan perbuatan Terdakwa yang mengakbatkan 2 (dua) orang korban yaitu saksi korban WARSONO RAKA SIWI mengalami luka berat dan saksi korban SRI ASTUTI SUDARSIH mengalami luka-luka, karena tidak mempertimbangkan perlunya diberikan efek jera bagi para pelaku tindak pidana penganiayaan yang mengakibatkan luka berat dan tindak pidana kekerasan fisik dalam lingkup rumah tangga, sehingga jika para pelaku tindak pidana tersebut diberi hukuman ringan maka dikhawatirkan akan terulang kembali tindak pidana tersebut di kemudian hari;

e. Hakim Mahkamah Agung mempertimbangkan alasan permohonan kasasi dari Pemohon Kasasi / Penuntut Umum tersebut, Mahkamah Agung berpendapat sebagai berikut: Bahwa alasan kasasi Penuntut Umum tidak dapat dibenarkan karena putusan Judex Factil Pengadilan Tinggi Yogyakarta yang menguatkan putusan Pengadilan Negeri Sleman yang menyatakan Terdakwa terbukti bersalah melakukan tindak pidana "Penganiayaan dan melakukan perbuatan kekerasan fisik dalam lingkup rumah tangga", dan menjatuhkan pidana kepada Terdakwa dengan pidana 
penjara selama 1 (satu) tahun, sudah tepat dan benar dalam pertimbangan hukumnya, oleh karena itu Judex Facti tidak salah dalam menerapkan hukum;

f. Selanjutnya Hakim Mahkamah Agung menerangkan bahwa keberatan kasasi Penuntut Umum mengenai berat ringannya pidana yang dijatuhkan kepada Terdakwa. Hal tersebut merupakan wewenang Judex Facti untuk menentukannya dan tidak tunduk pada penilaian dalam pemeriksaan tingkat kasasi; in casu Judex Facti juga telah mempertimbangkan dengan cukup mengenai keadaan yang memberatkan dan yang meringankan Terdakwa, termasuk Judex Facti telah mempertimbangkan mengenai adanya perdamaian antara Terdakwa dengan saksi korban WARSONO RAKA SIWI serta antara Terdakwa dan istri Terdakwa yang menjadi korban kekerasan, mereka telah berdamai dan berjanji untuk memulai membangun kembali kehidupan rumah tangga yang lebih baik;

g. Pada akhirnya, Hakim Mahkamah Agung menyatakan bahwa tidak ada alasan lagi bagi Mahkamah Agung untuk menilai pidana dan pemidanaan yang telah dijatuhkan oleh Judex Facti a quo. Lagi pula ternyata, putusan Judex Facti dalam perkara ini tidak bertentangan dengan hukum dan/atau Undang-Undang, maka permohonan kasasi Penuntut Umum tersebut harus ditolak.

\section{Analisis penulis terhadap Putusan Mahkamah Agung Nomor :} 992 K/Pid.Sus/2017

Adapun Amar Putusan Mahkamah Agung dalam Putusan Nomor : 992 K/Pid.Sus/2017, pada pokoknya menyatakan bahwa menolak permohonan kasasi dari Pemohon Kasasi/Penuntut Umum pada Kejaksaan Negeri Sleman, yang artinya bahwa secara otomatis Hakim Mahkamah Agung menguatkan dan membenarkan Putusan Pengadilan Negeri Sleman Nomor 472/Pid.Sus/2016/PN.Smn dan Putusan Putusan Pengadilan Tinggi Yogyakarta Nomor: 3/Pid.Sus/2017/PT YYK. 
Adapun alasan hukum Hakim Mahkamah Agung menyatakan demkian adalah bahwa keberatan kasasi Penuntut Umum mengenai berat ringannya pidana yang dijatuhkan kepada Terdakwa. Hal tersebut merupakan wewenang Judex Facti untuk menentukannya dan tidak tunduk pada penilaian dalam pemeriksaan tingkat kasasi, in casu Judex Facti juga telah mempertimbangkan dengan cukup mengenai keadaan yang memberatkan dan yang meringankan Terdakwa, termasuk Judex Facti telah mempertimbangkan mengenai adanya perdamaian antara Terdakwa dengan saksi korban WARSONO RAKA SIWI serta antara Terdakwa dan istri Terdakwa yang menjadi korban kekerasan, mereka telah berdamai dan berjanji untuk memulai membangun kembali kehidupan rumah tangga yang lebih baik, menurut Peneliti keputusan tersebut sudah sesuai karena memenuhi unsurunsur dalam pengambilan keputusan oleh Hakim.

Analisis penulis merujuk pada alasan Pemohon Kasasi (Penuntut Umum) yang menyatakan bahwa yang seharusnya terbukti adalah dakwaan Kesatu Primair yaitu Terdakwa NOVI TRIONO alias NOPE bin ISHAK MARIM melakukan tindak pidana penganiayaan berat sebagaimana diatur dan diancam pidana dalam Pasal 351 Ayat (2) KUHP, sehingga Pemohon Kasasi menyatakan bahwa Majelis Hakim telah salah atau keliru menafsirkan unsur luka berat dalam Pasal 351 Ayat (2) KUHP sebagaimana dalam pertimbangan Putusan Pengadilan Negeri Sleman di Sleman Nomor 472/Pid.Sus/2016/PN.Smn tanggal 13 Desember 2016 pada halaman 20 menyatakan bahwa "Menimbang, bahwa berdasarkan pertimbangan tersebut Majelis Hakim berpendapat bahwa unsur penganiayaan yang mengakibatkan luka berat tidak terpenuhi”, sehingga dalam amar putusannya membebaskan Terdakwa NOVI TRIONO alias NOPE bin ISHAK MARIM dari dakwaan Kesatu Primair.

Menurut analisa penulis bahwa Hakim Mahkamah Agung hendaknya tidak menolak permohonan kasasi dari Penuntut Umum tersebut karena Pemohon Kasasi mempermasalahkan mengenai penerapan hukum Hakim Pada Pengadilan Negeri dan Hakim Pada Pengadilan Tinggi Negeri yang menjatuhkan hukuman kepada pelaku atau Terdakwa dengan merujuk pada Dakwaan Subsidair. 
Lagipula, Pemohon Kasasi telah menjelaskan permasalahannya yaitu kekeliruan pada judex facti yaitu salah atau keliru menafsirkan unsur luka berat dalam Pasal 351 Ayat (2) KUHP. Artinya bahwa seharusnya patut secara hukum Hakim Mahkamah Agung menerima dan mempertimbangkan alasan permohonan kasasi dari Penuntut Umum tersebut.

Berkaitan dengan itu, penulis menganalisis Pasal 351 Ayat (2) KUHP yang menjadi alasan permohonan kasasi dari Penuntut Umum. Perlu diketahui bahwa bunyi Pasal 351 Ayat (2) KUHP adalah Jika perbuatan mengakibatkan luka-luka berat, yang bersalah diancam dengan pidana penjara paling lama lima tahun. Dari bunyi pasal tersebut, terlihat sangat jelas bahwa pasal inilah yang memuat unsur pidana yang seharusnya dipenuhi oleh Terdakwa karena saksi korban memang mengalami luka berat yang dibuktikan dengan Visum et Repertum tanggal 21 Agustus 2016 atas nama WARSONO RAKA SIWI.

Oleh karena itu, seharusnya Hakim Mahmakah Agung menerima permohonan kasasi dari Penuntut Umum karena memang Penuntut umum mempersoalkan masalah penafsiran hukum dan penerapan hukum yang diberikan oleh judex facti dan bukan semata-mata untuk mempermasalahkan berat ringannya hukuman sebagaimana disebut oleh Hakim Mahkamah Agung dalam pertimbangan hukumnya. Sehingga secara judex juris seharusnya Hakim Mahkamah Agung menerima permohonan kasasi tersebut demi keadilan hukum dan penegakan hukum terhadap pelaku tindak pidana Kekerasan Dalam Rumah Tangga.

Lagipula, karena perbuatan si Terdakwa mengakibatkan 2 orang korban dengan luka berat yang seharusnya dapat menambah keyakinan Hakim Mahkamah Agung untuk menerima permohan kasasi itu. Karena pada judex facti terdakwa hanya di hukum 1 (satu) tahun penjara tanpa pidana denda, padahal korban 2 orang dan mengalami luka berat. Maka, seharusnya korban dapat dipidana lebih tinggi sehingga menimbulkan efek jera bagi pelaku.

Dengan demikian, berdasarkan analisis penulis tersebut dapat disimpulkan bahwa Putusan Hakim Mahkamah Agung Nomor: 992 K/Pid.Sus/2017 
bertentangan dengan kewenangan judex juris karena tidak menerima permohonan kasasi dari Penuntut Umum yang secara jelas mempermasalahkan penerapan hukum pada judex facti. Maka, penulis patut menyatakan bahwa Putusan Hakim Mahkamah Agung Nomor: 992 K/Pid.Sus/2017 tidak memuat rasa keadilan dan tidak memuat prinsip penegakan hukum.

\section{Penutup}

Perlindungan hukum terhadap korban tindak pidana Kekerasan dalam Rumah tangga adalah upaya pemulihan korban KDRT menjadi salah satu hal yang tidak terpisahkan dari proses hukum. Dalam hal ini sudah menjadi tanggung jawab bersama antara pemerintah dan penyedia layanan baik layanan medis, psikologis, hukum dan rumah aman.

Bahwa berdasarkan analisis penulis pertimbangan Hakim Mahkamah Agung dalam perkara Nomor : 992 K/Pid.Sus/2017 bertentangan dengan kewenangan judex juris karena tidak menerima permohonan kasasi dari Penuntut Umum yang secara jelas mempermasalahkan penerapan hukum pada judex facti. Maka, penulis patut menyatakan bahwa Putusan Hakim Mahkamah Agung Nomor: 992 K/Pid.Sus/2017 tidak memuat rasa keadilan dan tidak memuat prinsip penegakan hukum.

Diharapkan kepada semua pihak dalam hal ini keluarga korban, pemerintah dan penegak hukum untuk memberikan perlindungan hukum terhadap korban tindak pidana Kekerasan Dalam Rumah Tangga, sehingga dapat tercapai tujuan perlindungan hukum dan penghormatan terhadap hak-hak asasi manusia dan hakhak korban.

Diharapkan kepada Hakim Mahkamah Agung dalam memeriksa dan memutus perkara terkait judex juris hendaknya dalam pertimbangannya lebih mengutamakan asas keadilan dan prinsip penegakan hukum agar terciptanya tujuan dari hukum itu sendiri yaitu menciptakan ketertiban, ketentraman, dan kedamaian, dan membuat setiap permasalahan dapat diselesaikan dengan adil melalui pengadilan dengan menjalankan ketentuan hukum yang berlaku. 


\section{Daftar Pustaka}

Amiruddin, Zainal Asiki, 2012, Pengantar Metode Penelitian Hukum, (Jakarta: Rajawali Pers)

Arief, Barda Nawawi, 2010, Masalah Penegakan Hukum dan Kebijakan Hukum Pidana Dalam Penanggulangan Kejahatan, (Jakarta:Kencana Prenada Media Group)

Arto, H. A. Mukti, 2008, Praktek Perkara Perdata Pada Pengadilan Agama, (Yogyakarta: Pustaka Pelajar)

Fuadi, Munir, 2018, Metode Riset Hukum : Pendekatan Teori dan Konsep, (Jakarta: PT.Raja Grafido Persada)

Hendrawati, Heni dan Agna Susila, 2017, Kajian Yuridis PP No 4 Tahun 2006 Tentang Penyelenggaraan dan Pemulihan Korban Kekerasan Dalam Rumah Tangga, Fakultas Hukum Universitas Muhammadiyah Magelang, Jurnal Hukum Vol 13 No.2

https://zirscorp.wordpress.com/2019/02/28/hak-korban-kdrt-dari-pemerintah-danmasyarakat/diakses tanggal 28 Juni 2021

Khaleed, Badriyah, 2015, Penyelesaian Hukum Kekerasan dalam Rumah Tangga Penghapusan Kekerasan dalam Rumah Tangga dan Upaya Pemulihannya, (Yogyakarta: Pustaka Yustisia)

Soekanto, Soerjono, 2012, Sosiologi Suatu Pengantar, (Jakarta: PT. Raja Grafindo Persada)

Soeroso, Moerti Hadiati, 2011, Kekerasan Dalam Rumah Tangga, (Jakarta:Sinar grafika)

Suratman, 2015, Metode Penelitian Hukum, (Bandung: Alfabeta, CV.)

Thahir, Ahmad, 2014, Hukum dalam Rumah Tangga, (Jakarta: Internusa Press)

Undang-Undang Republik Indonesia Nomor 1 tahun 1946 tentang Aturan Hukum Pidana. 
Undang-Undang Nomor 8 tahun 1981 tentang Hukum Acara Pidana.

Undang-Undang Republik Indonesia Nomor 23 Tahun 2004 tentang Penghapusan Kekerasan dalam Rumah Tangga.

Undang-Undang Republik Indonesia Nomor 48 Tahun 2009 Tentang Kekuasaan Kehakiman. 